\title{
Associative diazotrophic bacteria from forage grasses in the Brazilian semi-arid region are effective plant growth promoters
}

\author{
Gabiane dos Reis Antunes ${ }^{\mathrm{A}}$, Sheilla Rios Assis Santana ${ }^{\mathrm{A}}$, Indra Elena Costa Escobar ${ }^{\mathrm{B}}$, \\ Marivaine da Silva Brasil C, Gherman Garcia Leal de Araújo D, Tadeu Vinhas Voltolini ${ }^{\mathrm{D}}$, \\ and Paulo Ivan Fernandes-Júnior ${ }^{\mathrm{D}, \mathrm{E}}$

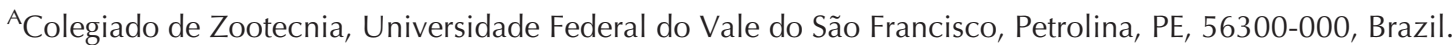 \\ ${ }^{B}$ Colegiado de Farmácia, Universidade Federal do Vale do São Francisco, Petrolina, PE, 56304-917, Brazil. \\ ${ }^{C}$ Campus Pantanal, Universidade Federal do Mato Grosso do Sul, Corumbá, MS, 79304-902, Brazil. \\ DEmbrapa Semiárido, Petrolina, PE, 56302-970, Brazil. \\ ECorresponding author. Email: paulo.ivan@embrapa.br
}

\begin{abstract}
The study of plant growth-promoting bacteria (PGPB) can identify outstanding bacteria for crops. For forage grasses adapted to drylands, the selection of PGPB can increase the field performance of pastures. The aim of this study was to isolate, and characterise at molecular, biochemical and symbiotic levels, diazotrophic bacteria obtained from buffel grass (Cenchrus ciliaris), sorghum (Sorghum bicolor) and Tifton 85 (Cynodon spp.) from Brazilian semi-arid region fields. Fieldgrown plants were collected, and the roots were surface-disinfected, crushed and inoculated in a semi-solid medium. After the formation and confirmation of microaerophilic pellicles, the bacteria were isolated and purified. All bacterial isolates were subjected to nifH gene amplification and identified by their partial 16S rRNA gene sequences. The bacteria were evaluated for the production of auxins and siderophores, calcium phosphate solubilisation, and diazotrophic ability as 'in vitro' plant growth-promotion traits. A plant inoculation assay was conducted to assess the plant growthpromotion abilities of the bacterial isolates. Twenty-one bacterial isolates harboured the nifH gene (nif $H^{+}$), among which nine were obtained from sorghum, eight from buffel grass, and four from Tifton 85 . The bacterial isolates were classified as Bacillus (8), Stenotrophomonas (7), Agrobacterium (4), Cellulomonas (1) and Paenibacillus (1). All were shown to be auxin producers, with 14 isolates showing diazotrophic capacity 'in vitro'. Fourteen isolates increased plant N content, but the bacterial strains ESA 392 and ESA 398 (Bacillus), ESA 397 and ESA 407 (Stenotrophomonas), and ESA 401 (Agrobacterium) were shown to promote both plant growth and N nutrition. These strains are candidates for further assays to evaluate their agronomic performance under field conditions, aiming inoculant production for forage grasses in drylands.
\end{abstract}

Additional keywords: biological nitrogen fixation, Caatinga, plant growth promotion traits, strain selection.

Received 21 February 2019, accepted 14 August 2019, published online 22 October 2019

\section{Introduction}

The north-eastern region of Brazil is home to $65.6 \%$ of the country's sheep and $92.8 \%$ of its goats, constituting more than 22 million animals (IBGE 2017). Most of these animals are raised in the semi-arid belt on family-based farms lacking expensive technologies for animal nutrition (Voltolini 2011). In drylands, most sheep and goats are not supplied food and they often graze natural shrub vegetation known as 'Caatinga', a Brazilian stepic savannah that does not have the food quality necessary to achieve high bodyweight (Moreira et al. 2006; Moreira and Guimarães Filho 2011). In this context, the development of highly productive pasture lands is important to increase animal production in the region.

Generally, forages require high amounts of fertilisers for suitable growth and development. The grasses in pastures require large amounts of nitrogen $(\mathrm{N})$, resulting in hundreds of kilograms of $\mathrm{N}$ fertilisers being applied per hectare, leading to high $\mathrm{N}$ losses, and the greenhouse-gas emissions (Signor and Cerri 2013; Mazzetto and Barneze 2016). The development and implementation of new, sustainable technologies for pastures in the Brazilian semi-arid region is needed, and to this end, the selection of new, locally adapted plant growth-promoting bacteria (PGPB) is a promising tool (Hungria et al. 2016; da Silva et al. 2018).

The PGPB comprise several bacterial taxa that are able to influence plant growth positively through several different mechanisms such as biological nitrogen fixation (BNF), phosphorus and potassium mobilisation, biological pest and disease control, and plant hormone regulation (Boddey et al. 1997; Glick 2005; de Souza et al.2015). Among these processes, BNF is one of the best understood, and $\mathrm{N}_{2}$-fixing bacteria can easily be obtained using semi-solid media (Baldani et al. 2014). 
Efforts to select for diazotrophic PGPB in Brazil culminated in the official recommendation and use of Azospirillum brasilense strains for maize (Zea mays L.), wheat (Triticum aestivum L.), rice (Oryza sativa L.) and Brachiaria spp. (Hungria et al. 2010, 2016). Recently, these bacteria were also demonstrated to be efficient plant growth promoters for other pasture grasses, such as sorghum (Sorghum bicolor (L.) Moench) (da Silva et al. 2018), Marandu grass (Urochloa brizantha (Hochst. ex A.Rich.) R.Webster) (Leite et al. 2019a) and Mombasa grass (Megathyrsus maximus (Jacq.) B.K.Simon \& S.W.L.Jacobs.) (Leite et al. 2019b).

Studies involving the selection of diazotrophic PGPB for forages have been conducted in vastly different regions of Brazil, including the mid-west (Reis Junior et al. 2004; Brasil et al. 2005; Souza et al. 2017), south-east (dos Santos et al. 2017) and northeast (dos Santos et al. 2013; Moreira et al. 2013; Antunes et al. 2017; da Silva et al. 2018), indicating the effectiveness of prospective studies for locally adapted $\mathrm{N}_{2}$-fixing isolates.

Few reports are available regarding the diversity and efficiency of PGPB from forage grasses in the semi-arid region of Brazil. Diazotrophic isolates from buffel grass (Cenchrus ciliaris L.), andropogon (Andropogon gayanus Kunth) and Tanzania grass (Panicum maximum Jacq. cv. Tanzânia) were previously obtained and phenotypically characterised from Patos, Paraíba State (dos Santos et al. 2013). At the same location, Moreira et al. (2013) isolated and characterised Azospirillum-like bacteria from the same plant species. Both studies characterised and evaluated the cultural diversity and seasonal fluctuation of diazotrophs but did not evaluate their molecular and plant growth-promotion abilities. More recently, a comprehensive study evaluated the molecular diversity and plant growth-promotion potential of field-grown sorghum in Petrolina, Pernambuco State, the results of which pointed towards an Enterobacter sp. isolate (ESA 57) as the most promising plant growth promoter (da Silva et al. 2018). However, a comprehensive study evaluating the molecular characteristics, plant growth-promotion abilities and symbiotic efficiency of those bacteria were not conducted for multiple field-grown grasses in the Brazilian semi-arid region.

Among the crop pastures grown in the Brazilian drylands, buffel grass, Tifton 85 (Cynodon spp.) and sorghum are the most widely distributed. Buffel grass and sorghum are cropped in rainfed systems, whereas Tifton 85 is recommended for use in irrigated pastures (Voltolini 2011). This partition covers the majority of the livestock systems in the Brazilian semi-arid region, and the isolation of bacteria from these different plants could be applied in different crop systems in the region. In this context, we hypothesised that field-grown buffel grass, sorghum and Tifton 85 harbor a diversity of efficient PGPB. Thus, the aim of this study was to isolate and evaluate the molecular diversity, plant growth-promotion abilities and characteristics of PGPB from field-grown buffel grass, Tifton 85 and sorghum in Petrolina municipality, Brazilian semi-arid region. This is more suitable because the isolation of the bacteria were conducted from plants in the same experimental field.

\section{Methods and materials}

\section{Isolation of bacteria}

Samples of roots of buffel grass (cv. Biloela), Tifton 85 and forage sorghum (cv. BRS Ponta Negra) were collected in the
Caatinga Experimental Field, an experimental area of Embrapa Semiárido, Petrolina, Pernambuco State $\left(9^{\circ} 03^{\prime} 45^{\prime \prime} \mathrm{S}\right.$, $\left.40^{\circ} 19^{\prime} 37^{\prime \prime} \mathrm{W}\right)$, in May 2015. For the sampling, three replicate samples of each species, two plants per replicate, were collected.

The roots were washed with tap water and surface-disinfested by immersion in $1 \%(\mathrm{v} / \mathrm{v})$ sodium hypochlorite for $10 \mathrm{~min}$, followed by 10 washes in deionised autoclaved water. The disinfected roots were weighed $(10 \mathrm{~g})$ and crushed with $90 \mathrm{~mL} 0.85 \%(\mathrm{w} / \mathrm{v}) \mathrm{NaCl}$ solution in a common blender. A serial dilution from $10^{-1}$ to $10^{-6}$ was performed, and for each dilution, $100 \mu \mathrm{L}$ was inoculated into flasks containing $7 \mathrm{~mL}$ BMGM semi-solid medium (per L: 1 g glucose, 2 g malic acid, $1 \mathrm{~g}$ mannitol, $400 \mathrm{mg} \mathrm{K}_{2} \mathrm{HPO}_{4}, 400 \mathrm{mg} \mathrm{KH} \mathrm{PO}_{4}, 200 \mathrm{mg} \mathrm{MgSO}$, $20 \mathrm{mg} \mathrm{CaCl}_{2}, 2 \mathrm{mg} \mathrm{NaMoO}_{4}$, and $10 \mathrm{mg} \mathrm{FeSO}_{4} ; 2$ g agar, pH 6.0) (Estrada-de Los Santos et al. 2001) and incubated at $28^{\circ} \mathrm{C}$ for 10 days. Each serial dilution was inoculated in triplicate. Afterwards, the less-concentrated dilutions that developed a typical microaerophilic pellicle (MP) were separated, reinoculated in the same medium, and incubated at the same conditions. The flasks with positive MP were streaked onto plates containing Dyg's medium (per L: 2 g glucose, 2 g malic acid, $1.5 \mathrm{~g}$ peptone, $2 \mathrm{~g}$ yeast extract, $500 \mathrm{mg} \mathrm{K}_{2} \mathrm{HPO}_{4}$, $500 \mathrm{mg} \mathrm{MgSO}_{4}, 1.5 \mathrm{~g}$ glutamic acid, and $15 \mathrm{~g}$ agar; $\mathrm{pH}$ 6.5) (Rodrigues Neto et al. 1986).

Both BMGM and Dyg's are nonselective culture media, and the isolation of diazotrophic isolates in BMGM semi-solid, coupled with the use of Dyg's solid media, can retrieve a large diversity of diazotrophic bacteria (Fernandes Júnior et al. 2013, 2015). For these reasons, this isolation strategy was applied in the present study. The purified colonies were stored in glycerol at $-80^{\circ} \mathrm{C}$ in the Culture Collection of Microorganisms with Agricultural Interests of Embrapa Semiárido (CMISA).

\section{Molecular analyses}

All bacteria grew in liquid Dyg's medium, and DNA was extracted by using the alkaline lysis method as described by Wang et al. (1993). All bacteria were subjected to nifH amplification, using the primers PolF (TGCGAYCCSAA RGCBGACTC) and PolR (ATSGCCATCATYTCRCCGGA) (Poly et al. 2001). Afterwards, nested PCR, where the first PCR product is used as a template for the second reaction, was performed to evaluate the presence of the negative isolates in the first reaction. For nested PCR, the primers NifHfor (ACCCGCCTGATCCTGCACGCAAGG) and NifHrev (ACG ATGTAGATTTCCTGGGCCTTGTT) (Soares et al. 2006) were used.

The 16S rRNA gene was amplified by using the universal primers 27F (GAGTTTGATCCTGGCTCAG) and 1492R (GGTTACCTTGTTACGACTT) (Weisburg et al. 1991), and the PCR products were purified using a Wizard SV Gel and PCR Clean-up System kit (Promega, Madison, WI, USA). Sequencing was conducted at Macrogen (Seoul, South Korea), using an Applied Biosystems 3730xl Genetic Analyzer (Thermo Fisher, Waltham, MA, USA) with the primer 27F. The quality of the sequences was verified using Applied Biosystems Sequence Scanner version 2.0 (Thermo Fisher), and the high-quality sequences (QV $>20$ in 800-bp continuous reads) were compared by using the EzBioCloud database (Yoon et al. 
2017). The sequences were deposited in the GenBank database of the National Center for Biotechnology Information (https:// www.ncbi.nlm.nih.gov/genbank/) under the accession numbers MK424592-MK424613.

\section{In vitro plant growth-promoting traits}

For evaluation of auxin production, the colourimetric procedure described by Sarwar and Kremer (1995) was used, with some modifications. Briefly, the bacteria were grown in liquid Dyg's medium with or without $100 \mathrm{mg} \mathrm{L}^{-1}$ of L-tryptophan (L-Trp) for 7 days under constant stirring of $120 \mathrm{rpm}$ at room temperature. The optical density of each culture was adjusted spectrophotometrically at $600 \mathrm{~nm}\left(\mathrm{OD}_{600}\right)$ to 0.3 to standardise the cell concentration.

Subsequently, $1.0-\mathrm{mL}$ aliquots of the $\mathrm{OD}_{600}$-adjusted cultures were centrifuged for $3 \mathrm{~min}$ at $6000 \mathrm{~g}$, after which $150 \mu \mathrm{L}$ supernatant was added to 96-well ELISA microplates along with $100 \mu \mathrm{L}$ Salkowski's reagent $(1.0 \mathrm{~mL} 0.5 \mathrm{M}$ $\mathrm{FeCl}_{3} \cdot 6 \mathrm{H}_{2} \mathrm{O}$ and $50 \mathrm{~mL} 35 \%(\mathrm{v} / \mathrm{v}) \mathrm{HClO}_{4}$ ). The plates were stored in the dark at room temperature for $30 \mathrm{~min}$, after which the intensity of the reddish coloration was determined spectrophotometrically at $530 \mathrm{~nm}$. The auxin concentration was estimated by using a standard curve with a known concentration of indole acetic acid (Sigma Aldrich, St. Louis, MO, USA).

For siderophore production, the qualitative approach described by Ribeiro and Cardoso (2012) was adapted. Briefly, the isolates were grown in Dyg's medium for 4 days as described above. Afterwards, a 1-mL sample of the culture was centrifuged, and $150 \mu \mathrm{L}$ supernatant was added to 96-well ELISA microplates along with $150 \mu \mathrm{L}$ CAS reagent $(6.0 \mathrm{~mL}$ hexadecyltrimethylammonium bromide (HDTMA), $1.5 \mathrm{~mL}$ $\mathrm{FeCl}_{3} \cdot 6 \mathrm{H}_{2} \mathrm{O}$ solution, $4.307 \mathrm{~g}$ piperazine, and $6.25 \mathrm{~mL} 33 \%$ (v/v) HCl) (Schwyn and Neilands 1987). The plates were incubated in the dark at room temperature for $30 \mathrm{~min}$, and wells that changed from blue to yellow-orange were considered positive.

The isolates were evaluated for tricalcium phosphate solubilisation in solid medium (Sylvester-Bradley et al. 1982). The bacteria were cultured in liquid Dyg's medium for 4 days, centrifuged and resuspended as described above. Subsequently, $10-\mu \mathrm{L}$ aliquots of the cultures were placed into plates containing GL (glucose-yeast extract) medium (per L: $10 \mathrm{~g}$ glucose, $2 \mathrm{~g}$ yeast extract with $50 \mathrm{~mL} \mathrm{~K}_{2} \mathrm{HPO}_{4}$ and $100 \mathrm{~mL} \mathrm{CaCl}_{2}$ (both $10 \% \mathrm{w} / \mathrm{v})), 20 \mathrm{~g}$ agar and incubated at room temperature for 6 days. After the incubation period, the diameters of the colonies and the translucent halo surrounding the colonies were measured. The data were used to calculate the solubilisation index via the ratio diameter of halo: diameter of colony (Berraquero et al. 1976).

Putative diazotrophic ability was assessed by quantifying the $\mathrm{N}$ content in semi-solid medium after MP formation (Kuss et al. 2007; Silva et al. 2013; Fernandes-Júnior et al. 2015). Flasks with $10 \mathrm{~mL}$ BMGM semi-solid medium were inoculated with $100-\mu \mathrm{L}$ samples of the bacterial cultures and incubated at room temperature for 10 days. After the incubation period, the medium was manually homogenised, frozen at $-20^{\circ} \mathrm{C}$ and heated in boiling water for $10 \mathrm{~min}$. Subsequently, the media samples were homogenised again, and 5-mL aliquots were withdrawn to quantify the $\mathrm{N}$ content by using the modified Devarda's alloy semi-micro Kjeldahl method (Liao 1981). To calculate the
$\mathrm{N}$ concentration inputted into the medium by the bacteria, an aliquot of uninoculated BMGM medium was also digested and distilled as a blank.

All 'in vitro' plant growth-promotion traits were assessed with three replications applied in a completely randomised design. For all experiments, the commercial inoculant bacterium Azospirillum brasilense (Ab-V5) for Brachiaria spp. was also evaluated.

\section{Plant growth-promotion assay}

All bacterial isolates were assessed in pot experiments to evaluate their plant growth-promotion abilities. The experiment was performed in 5-L pots filled with a layer sample of red-yellow Ultisol. A soil sample was used for soil chemical analysis (results are shown in the Supplementary Material table S1, available at the journal's website). The model plant sorghum (cv. BRS Ponta Negra) was used.

The seeds were surface-disinfected with $96 \%$ (v/v) ethanol for $30 \mathrm{~s}$ and $2.5 \%(\mathrm{v} / \mathrm{v})$ sodium hypochlorite for $5 \mathrm{~min}$; they were then washed 10 times with deionised autoclaved water. For inoculation, the bacterial isolates were grown in liquid Dyg's medium for 4 days as described above. Four seeds were sown per pot, and 1-mL aliquots of the cultures were inoculated over each seed. The experimental treatments included single inoculations of 21 new bacteria and the reference strain Ab-V5. In addition, three uninoculated treatments, one without mineral $\mathrm{N}$ and two with the addition of 50 and $100 \mathrm{mg} \mathrm{N}\left(\mathrm{NH}_{4} \mathrm{NO}_{3}\right)$ per plant per week, starting in the second week, were also tested. For application to each pot, $\mathrm{NH}_{4} \mathrm{NO}_{3}$ was weighted, dissolved in $100 \mathrm{~mL}$ deionised autoclaved water and applied after the daily irrigation.

At 10 days after emergence, the plants were thinned such that a single plant remained per pot. The plants received $500 \mathrm{~mL}$ tap water daily and were harvested at 62 days after emergence. The roots were separated from the shoots and carefully washed with running tap water, after which they were separately dried at $65^{\circ} \mathrm{C}$ in an oven and weighed. The shoots were milled, and the total $\mathrm{N}$ concentration was assessed by Devarda's alloy semi-micro Kjeldahl method (Liao 1981). A completely randomised block design was applied with four replications per treatment.

\section{Statistical analyses}

All quantitative data were analysed by one-way analysis of variance (ANOVA). Prior to analysis of variance the data were transformed by calculating the square roots of data added to 1 (i.e. $\left.(x+1)^{0.5}\right)$ to meet the assumptions of a normal distribution of errors and homoscedascity. The Scott-Knott mean range test $(P>0.05)$ was applied to all variables after the ANOVA. Statistical analyses were performed in Sisvar version 5.0 (Ferreira 2011).

\section{Results}

Isolation and taxonomic classification of bacterial isolates by partial 165 rRNA gene sequence analysis

Twenty-one bacterial isolates were retrieved after the purification process and confirmation of MP formation, with the sorghum yielding nine, buffel grass eight and Tifton 85 plants yielding four bacterial isolates. Among these bacteria, all isolates 
were nifH-positive, with 13 yielding amplification products from the first PCR with the PolF/PolR primer pair, whereas eight bacteria showed positive amplification after the nested-PCR reaction using the primer pair NifHfor/NifHrev in the second PCR.

The partial $16 \mathrm{~S}$ rRNA sequence analysis showed that the bacterial isolates were clustered in the genera Bacillus (8), Stenotrophomonas (7), Agrobacterium (4), Cellulomonas (1) and Paenibacillus (1), with similarity to the sequences of type strains in the EzBioCloud database ranging from $95 \%$ to $100 \%$ (Table 1). Buffel grass harboured Bacillus (4), Stenotrophomonas (3) and Agrobacterium (2); sorghum hosted Stenotrophomonas (2), Bacillus (2), Agrobacterium (2) and Pseudomonas (1); and Tifton 85 plants were infected by Bacillus (2), Paenibacillus (1) and Stenotrophomonas (1).

\section{In vitro plant growth promotion traits}

All bacterial isolates were able to synthetise an amount of auxins in the media with or without L-Trp (Fig. 1). In the medium with L-Trp, the average auxin concentration ranged from $30.4 \mu \mathrm{g} \mathrm{mL}^{-1}$ for isolate ESA 407 to $243.0 \mu \mathrm{g} \mathrm{mL}^{-1}$ for ESA 391. In the medium without L-Trp, the bacterial isolates produced from $24.5 \mu \mathrm{g}$ auxins $\mathrm{mL}^{-1}$ (ESA 405) to $115.1 \mu \mathrm{g}$ $\mathrm{mL}^{-1}$ (ESA 410) on average. By contrast, the reference strain Ab-V5 produced, on average, 40.9 and $30.9 \mu \mathrm{g}$ auxins $\mathrm{mL}^{-1}$ in media with and without L-Trp, respectively. Theses averages were lower than observed in 17 new bacterial isolates in medium with or without L-Trp.

Regarding the diazotrophic capacity of all isolates, 14 of 21 bacteria showed the same level of $\mathrm{N}$ incorporation in media as the known efficient diazotrophic strain Azospirillum brasilense Ab-V5 (Fig. 2), indicating the high diazotrophic potential of the grass-associated bacteria. Positive results for siderophore production were observed only in the Ab-V5 reference strain and for the isolate ESA 408 obtained from Tifton 85 . Tricalcium phosphate solubilisation was positive for ESA 402 and Ab-V5 only (both with a solubilisation index of 1.1).

\section{Plant growth promotion assay}

Inoculation of newly isolated bacteria, and of the reference strain Ab-V5, improved the growth of roots and shoots as well as $\mathrm{N}$ accumulation in sorghum plants (Table 2). Higher averages for root biomass were observed in the plants with full $\mathrm{N}$ fertilisation and those inoculated with the ESA 411 (Stenotrophomonas) bacterium. However, the plants inoculated with Bacillus ESA 392, ESA 398, ESA 402, ESA 401, ESA 400 and ESA 410, with Stenotrophomonas ESA 397, ESA 407, ESA 405 and ESA 399, with Agrobacterium ESA 396 and ESA 401, with Paenibacillus ESA 408, and with Azospirillum brasilense Ab-V5 had the same root biomass as observed in the treatments with the $50 \% \mathrm{~N}$ fertilisation rate. These results indicate the potential of these strains to increase sorghum biomass.

The shoots of sorghum plants with $100 \%$ or $50 \% \mathrm{~N}$ fertilisation treatments and plants inoculated with Stenotrophomonas ESA 397, ESA 407, ESA 399, ESA 405 and ESA 411, with Bacillus ESA 392, ESA 398, ESA 402 and ESA 410, with Agrobacterium ESA 401, and with Azospirillum brasilense Ab-V5 were larger than those in the negative control and in the other inoculation treatments. The $\mathrm{N}$ accumulation in the shoots of plants inoculated with Azospirillum brasilense Ab-V5, with Stenotrophomonas ESA 397, ESA 407, ESA 403 and ESA 399, with Bacillus ESA 392, ESA 394 and ESA 398, with Agrobacterium ESA 395, ESA 401 and ESA 406, with Paenibacillus ESA 408, and with Cellulomonas ESA 393 was higher than observed in the negative control treatment and the other seven inoculation treatments.

Table 1. Identification of 21 bacterial isolates obtained from buffel grass (Cenchrus ciliaris), sorghum (Sorghum bicolor) and Tifton 85 (Cynodon spp.) plants in the Brazilian semi-arid region

\begin{tabular}{|c|c|c|c|c|c|}
\hline Bacterial isolate & $\begin{array}{c}\text { GenBank } \\
\text { accession code }\end{array}$ & Host & $\begin{array}{c}\text { Fragment } \\
\text { length (bp) }\end{array}$ & Closest type strains & Similarity $(\%)$ \\
\hline ESA 391 & MK424592 & Cenchrus ciliaris & 1068 & Stenotrophomonas pavanii (LMG $25348^{\mathrm{T}}$ ) & 99.3 \\
\hline ESA 392 & MK424593 & Cenchrus ciliaris & 1031 & Bacillus safensis $\left(\mathrm{FO}-36 \mathrm{~b}^{\mathrm{T}}\right)$ & 98.9 \\
\hline ESA 393 & MK424594 & Cenchrus ciliaris & 1009 & Cellulomonas massiliensis $\left(\mathrm{JC} 225^{\mathrm{T}}\right)$ & 97.1 \\
\hline ESA 394 & MK424595 & Cenchrus ciliaris & 1028 & Bacillus siamensis $\left(\mathrm{KCTC} 13613^{\mathrm{T}}\right)$ & 99.5 \\
\hline ESA 395 & MK424596 & Cenchrus ciliaris & 884 & Agrobacterium fabrum $\left(\mathrm{C} 58^{\mathrm{T}}\right)$ & 100.0 \\
\hline ESA 396 & MK424597 & Cenchrus ciliaris & 950 & Agrobacterium pusense $\left(\mathrm{NRCPB} 10^{\mathrm{T}}\right)$ & 96.4 \\
\hline ESA 397 & MK424598 & Cenchrus ciliaris & 1024 & Stenotrophomonas maltophilia $\left(\mathrm{NCTC} 10257^{\mathrm{T}}\right.$ ) & 99.3 \\
\hline ESA 398 & MK424599 & Cenchrus ciliaris & 1135 & Bacillus siamensis $\left(\mathrm{KCTC} 13613^{\mathrm{T}}\right)$ & 99.3 \\
\hline ESA 399 & MK424600 & Sorghum bicolor & 1094 & Stenotrophomonas pavanii (LMG $25348^{\mathrm{T}}$ ) & 98.5 \\
\hline ESA 400 & MK424601 & Sorghum bicolor & 1109 & Bacillus velezensis (NRRL B- $41580^{\mathrm{T}}$ ) & 99.1 \\
\hline ESA 401 & MK424602 & Sorghum bicolor & 1022 & Agrobacterium salinitolerans (YIC $5082^{\mathrm{T}}$ ) & 98.7 \\
\hline ESA 402 & MK424603 & Sorghum bicolor & 1082 & Bacillus safensis $\left(\mathrm{FO}-36 \mathrm{~b}^{\mathrm{T}}\right)$ & 100.0 \\
\hline ESA 403 & MK424604 & Sorghum bicolor & 999 & Stenotrophomonas pavanii (LMG $25348^{\mathrm{T}}$ ) & 99.2 \\
\hline ESA 404 & MK424605 & Sorghum bicolor & 1091 & Bacillus velezensis (NRRL B-41580 ${ }^{\mathrm{T}}$ ) & 98.8 \\
\hline ESA 405 & MK424606 & Sorghum bicolor & 1134 & Stenotrophomonas pavanii (LMG $25348^{\mathrm{T}}$ ) & 99.3 \\
\hline ESA 406 & MK424607 & Sorghum bicolor & 1102 & Agrobacterium salinitolerans (YIC $5082^{\mathrm{T}}$ ) & 98.5 \\
\hline ESA 407 & MK424608 & Sorghum bicolor & 993 & Stenotrophomonas bentonitica $\left(\mathrm{BII}-\mathrm{R} 7^{\mathrm{T}}\right)$ & 99.1 \\
\hline ESA 408 & MK424609 & Cynodon spp. & 1008 & Paenibacillus dongdonensis (KUDC0114 ${ }^{\mathrm{T}}$ ) & 98.7 \\
\hline ESA 409 & MK424610 & Cynodon spp. & 988 & Bacillus aryabhattai $\left(\mathrm{B} 8 \mathrm{~W} 22^{\mathrm{T}}\right)$ & 100.0 \\
\hline ESA 410 & MK424611 & Cynodon spp. & 990 & Bacillus velezensis (NRRL B-41580 ${ }^{\mathrm{T}}$ ) & 99.3 \\
\hline ESA 411 & MK424612 & Cynodon spp. & 1000 & Stenotrophomonas pavanii (LMG $25348^{\mathrm{T}}$ ) & 95.0 \\
\hline
\end{tabular}




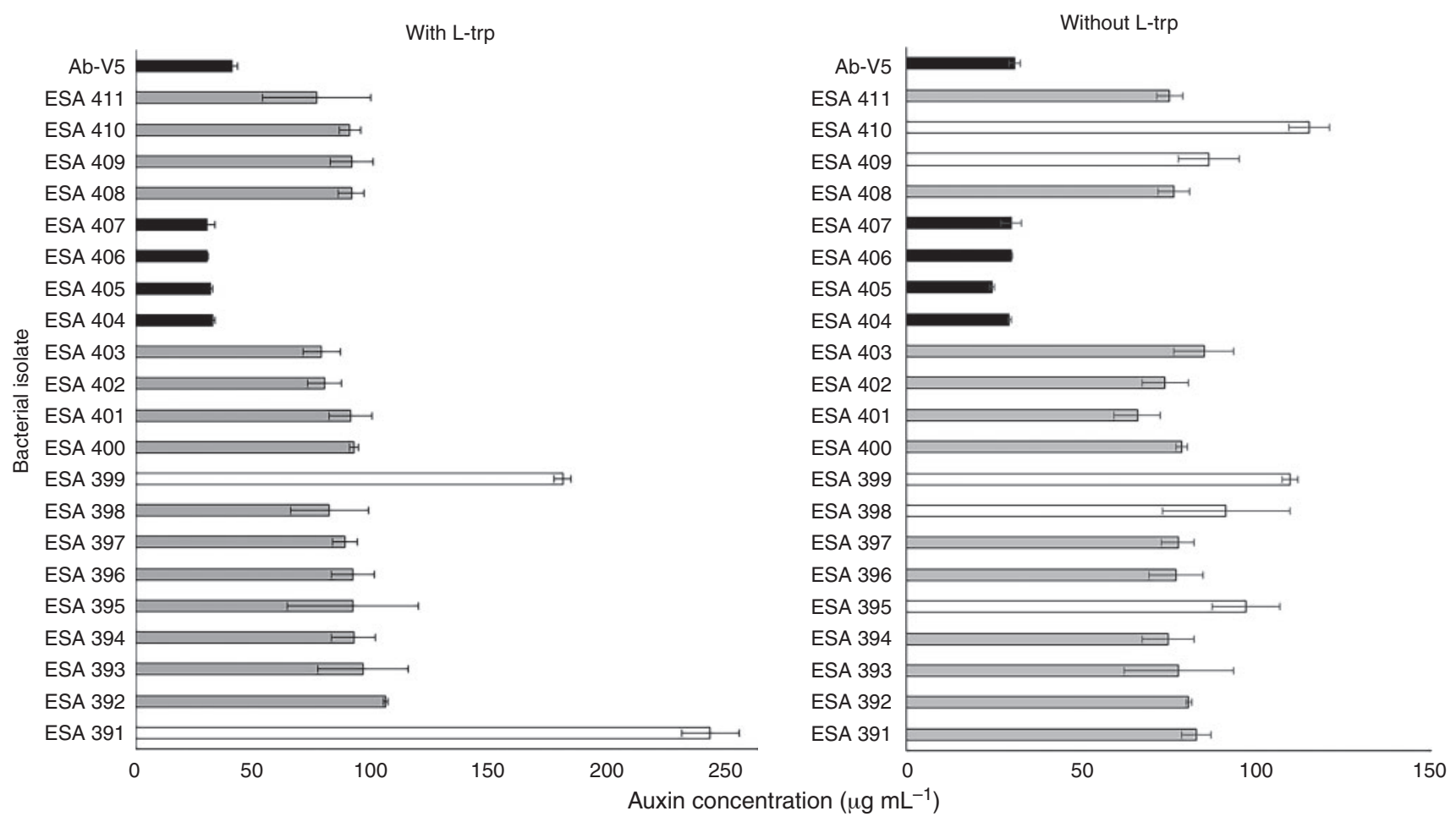

Fig. 1. In vitro auxin production by $21 \mathrm{new}$ diazotrophic bacteria from buffel grass, sorghum and Tifton 85 grass and by Azospirillum brasilense Ab-V5 in liquid medium with or without L-tryptophan. Data are averages of four replications. Capped lines are mean deviation errors. Bars with the same colour (in the same graphic) do not differ according to the Scott-Knott mean range test.

\section{Discussion}

Classification of the isolates at the genus level indicated the presence of five genera, among which Bacillus predominated. Members of this genus have the ability to form endospores, which are resistant structures that can withstand severe dehydration for long periods and can germinate when water becomes available (Ambrosini et al. 2016). In drylands, previous reports have described the association of Bacillus with rainfed native plants such as the Poaceae Tripogonella spicata (Nees) P.M.Peterson \& Romasch (formerly Tripogon spicatus (Nees) Ekman) (Fernandes-Júnior et al. 2015) and some cacti (Cactaceae) (Kavamura et al. 2013). By contrast, in other crop systems or pristine environments in the Brazilian semi-arid region, isolation efforts did not result in the identification of Firmicutes, whereas the prevalence of other taxonomic clusters such as Enterobacteriaceae (da Silva et al. 2018) and Burkholderiaceae (Lima et al. 2015) was observed.

In addition to Firmicutes, members of the $\gamma$-Proteobacteria genus Stenotrophomonas were isolated from the different plants studied. This genus was also obtained from T. spicata in the Brazilian Caatinga biome (Fernandes-Júnior et al. 2015) and from grasses in dry regions of India (Singh and Jha 2017) and Namibia (Haiyambo et al. 2015a), as well as from areas with other environmental conditions (Gontijo et al. 2018). Four Agrobacterium spp. were obtained from buffel grass and sorghum. This genus is endophytically associated with several non-legumes worldwide and exhibits numerous plantstimulation mechanisms (Bertrand et al. 2001; Vendan et al.
2010; da Silva et al. 2018). However, to the best of our knowledge, this is the first report of the identification of Agrobacterium spp. as growth-promoting bacteria isolated from buffel grass. In addition, for the first time, a single isolate belonging to the genus Cellulomonas (Actinobacteria, Micrococcales, Cellulomonadaceae) was obtained from buffel grass. Cellulomonas was previously isolated from crops grown under different environmental conditions (Egamberdiyeva and Höflich 2002; Zinniel et al. 2002), including semi-arid environments (Egamberdieva 2008).

The results of assays to assess plant growth-promoting mechanisms indicated great metabolic variability within the strain culture collection. All isolates produced more auxin than the reference strain in the medium without L-Trp, the primary auxin precursor. These results indicate that all isolates have different metabolic pathways to synthetise auxins, including the primary L-Trp-dependent route, as observed in Azospirillum. The production of auxins in culture medium is indicative of the plant growth-promoting abilities of the bacterial isolates (Barazani and Friedman 1999; Brígido and Oliveira 2013; Duca et al. 2014).

Only the Bacillus sp. isolate ESA 402 was able to solubilise tricalcium phosphate, whereas the Paenibacillus isolate ESA 408 was shown to be a siderophore producer. These findings are not in agreement with the results of previous studies conducted in the Brazilian semi-arid region, where the isolation of plant endophytic bacteria resulted in a culture collection with several isolates that were able to act as phosphate solubilisers and/or siderophore producers (Fernandes-Júnior et al. 2015; da 


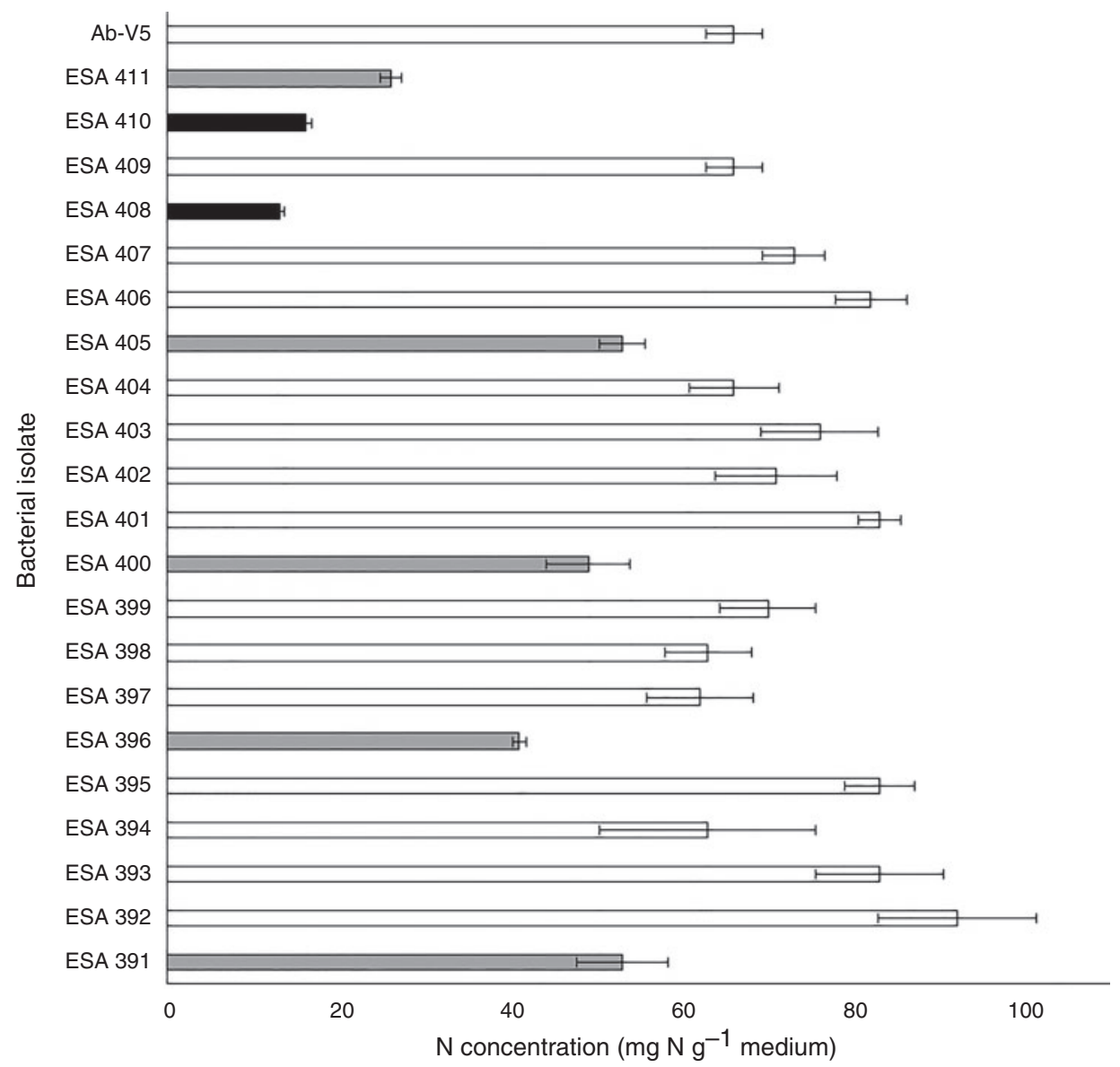

Fig. 2. Nitrogen concentration in BMGM semi-solid medium after microaerophilic growth of 21 new diazotrophic bacteria from buffel grass, sorghum and Tifton 85 grass and of Azospirillum brasilense Ab-V5. Data are averages of four replications. Capped lines are mean deviation errors. Bars with the same colour do not differ according to the Scott-Knott mean range test.

Silva et al. 2018; de Oliveira et al. 2018). Thus, ESA 402 and ESA 408 may be used to generate an inoculant mixture to improve the growth-promotion capacity of a consortium of bacteria.

An equivalent incorporation of $\mathrm{N}$ in medium was observed for 14 new bacterial isolates and the known diazotrophic species Azospirillum brasilense. In addition, among these 14 isolates, ESA 395, ESA 402 and ESA 409 were ranked in the highest clustering for auxin production (according to the Scott-Knott mean range test), reinforcing their multiple-plant growthpromotion abilities.

In the plant growth-promotion assays, the inoculation of 17 new strains, as well as the reference strain Ab-V5, led to some improvement in sorghum growth and/or N nutrition parameters, reinforcing that these strains are effective PGPB. The plant growth promoted by the bacterial isolates was associated with their putative diazotrophic capacities, because Ab-V5 and seven other $\mathrm{N}_{2}$-fixing isolates were able to promote $\mathrm{N}$ accumulation in plant shoots. Regarding the other plant growth-promotion mechanisms, in auxin production and $\mathrm{N}_{2}$-fixation assays, ESA 392 (Bacillus), ESA 397 (Stenotrophomonas), ESA 398 (Bacillus), ESA 401 (Agrobacterium) and ESA 407
(Stenotrophomonas) exhibited the capacity to promote root and shoot growth as well as increase $\mathrm{N}$ accumulation in plant shoots, reinforcing the potential of these bacteria to promote sorghum growth.

The bacterial isolates obtained in the present study are similar to PGPB isolates previously obtained from semi-arid environments and they increase the number of plant-associated genera isolated from crops, primarily for buffel grass. The results of the present study, together with those of similar studies, indicate a large diversity and local variability of bacteria associated with soils from the Brazilian semi-arid region, reinforcing the importance of our results regarding grassassociated bacteria in the Brazilian drylands.

The promotion of sorghum growth by bacterial isolates that were selected by assays assessing different plant growthpromotion mechanisms was already described in previous bacterial-isolation studies that used the semi-solid medium strategy (Haiyambo et al. 2015b; da Silva et al. 2018). These data reinforce the effectiveness of our bacterial strains, primarily for the isolates ESA 392, ESA 397, ESA 398, ESA 401 and ESA 407. In Brazil, sorghum, buffel grass and Tifton 85 do not have officially recommended bacterial strains for inoculant 
Table 2. Root dry mass (RDM), shoot dry mass (SDM) and total nitrogen in the shoots (TNS) of sorghum plants inoculated with 21 bacteria from three forage grasses and Azospirillum brasilense (Ab-V5) Within columns, averages followed by the same letter are not significantly different $(P>0.05)$ according to the Scott-Knott mean range test $(n=4)$

\begin{tabular}{lccc}
\hline Inoculation treatment & $\begin{array}{c}\text { RDM } \\
\left(\text { g plant }^{-1}\right)\end{array}$ & $\begin{array}{c}\text { NAS } \\
\left(\text { mg plant }^{-1}\right)\end{array}$ \\
\hline ESA 391 & $2.27 \mathrm{c}$ & $9.45 \mathrm{~b}$ & $166 \mathrm{a}$ \\
ESA 392 & $5.45 \mathrm{~b}$ & $22.92 \mathrm{a}$ & $213 \mathrm{a}$ \\
ESA 393 & $3.30 \mathrm{~b}$ & $12.87 \mathrm{~b}$ & $147 \mathrm{~b}$ \\
ESA 394 & $1.02 \mathrm{c}$ & $7.72 \mathrm{~b}$ & $140 \mathrm{~b}$ \\
ESA 395 & $1.72 \mathrm{c}$ & $11.17 \mathrm{~b}$ & $158 \mathrm{a}$ \\
ESA 396 & $0.67 \mathrm{c}$ & $6.52 \mathrm{~b}$ & $208 \mathrm{a}$ \\
ESA 397 & $4.40 \mathrm{~b}$ & $17.10 \mathrm{a}$ & $203 \mathrm{a}$ \\
ESA 398 & $2.65 \mathrm{~b}$ & $14.50 \mathrm{a}$ & $192 \mathrm{a}$ \\
ESA 399 & $3.57 \mathrm{~b}$ & $16.32 \mathrm{a}$ & $142 \mathrm{~b}$ \\
ESA 400 & $4.82 \mathrm{~b}$ & $18.42 \mathrm{a}$ & $168 \mathrm{a}$ \\
ESA 401 & $5.35 \mathrm{~b}$ & $18.65 \mathrm{a}$ & $170 \mathrm{a}$ \\
ESA 402 & $4.42 \mathrm{~b}$ & $16.90 \mathrm{a}$ & $100 \mathrm{~b}$ \\
ESA 403 & $5.70 \mathrm{~b}$ & $18.77 \mathrm{a}$ & $226 \mathrm{a}$ \\
ESA 404 & $2.37 \mathrm{c}$ & $7.32 \mathrm{~b}$ & $211 \mathrm{a}$ \\
ESA 405 & $1.40 \mathrm{c}$ & $10.42 \mathrm{~b}$ & $192 \mathrm{a}$ \\
ESA 406 & $3.37 \mathrm{~b}$ & $3.77 \mathrm{~b}$ & $144 \mathrm{~b}$ \\
ESA 407 & $3.86 \mathrm{~b}$ & $14.10 \mathrm{a}$ & $179 \mathrm{a}$ \\
ESA 408 & $3.05 \mathrm{~b}$ & $12.52 \mathrm{~b}$ & $176 \mathrm{a}$ \\
ESA 409 & $1.90 \mathrm{c}$ & $11.30 \mathrm{~b}$ & $131 \mathrm{~b}$ \\
ESA 410 & $5.97 \mathrm{~b}$ & $20.75 \mathrm{a}$ & $210 \mathrm{a}$ \\
ESA 411 & $9.77 \mathrm{a}$ & $23.08 \mathrm{a}$ & $113 \mathrm{~b}$ \\
Ab-V5 & $4.15 \mathrm{~b}$ & $15.05 \mathrm{a}$ & $158 \mathrm{a}$ \\
Negative control & $2.92 \mathrm{c}$ & $16.90 \mathrm{a}$ & $60 \mathrm{~b}$ \\
$50 \%$ N & $5.50 \mathrm{~b}$ & $14.53 \mathrm{a}$ & $210 \mathrm{a}$ \\
$100 \%$ N & $10.43 \mathrm{a}$ & $23.76 \mathrm{a}$ & $223 \mathrm{a}$ \\
\hline & & &
\end{tabular}

production. The results of the present study indicate that our culture collection harbors bacterial isolates (primarily those abovementioned) that should be assessed in further field studies aiming to develop new bacteria isolates for inoculant production according to the Brazilian standards for inoculant recommendations.

\section{Conclusions}

Buffel grass, sorghum and Tifton 85 are colonised by different taxa of PGPB. These diazotrophic bacteria, primarily members of the genera Bacillus, Stenotrophomonas and Agrobacterium, are effective at promoting plant growth and $\mathrm{N}$ nutrition, indicating that the bacterial isolates ESA 392, ESA 397, ESA 398, ESA 401 and ESA 407 are candidates as bacterial strains for inoculants for grasses in Brazilian drylands.

\section{Conflicts of interest}

The authors declare no conflicts of interest.

\section{Acknowledgements}

We thank the Brazilian Council for Scientific and Technological Development (CNPq 485168/2013-8), INCT_Plant Growth Promoting Microorganisms for Agricultural Sustainability and Environmental Responsibility (CNPq/Fundação Araucária STI/CAPES INCTMPCPAgro 465133/2014-4) and the Brazilian Agricultural Research
Corporation (Embrapa 23.13.08.003.00.00 and 20.18.03.066.00.00) for financial support. We also thank the Science Foundation of the Pernambuco State (FACEPE) for awarding a scholarship to the first author and the Coordination of Improvement of Higher Education Personnel (CAPES) for awarding scholarships to the second, sixth and seventh authors. The fifth and the last authors are research fellows of $\mathrm{CNPq}$. We thank the anonymous reviewers whose suggestions and recommendations improved the quality of this paper.

\section{References}

Ambrosini A, Stefanski T, Lisboa BB, Beneduzi A, Vargas LK, Passaglia LMP (2016) Diazotrophic bacilli isolated from the sunflower rhizosphere and the potential of Bacillus mycoides $\mathrm{B} 38 \mathrm{~V}$ as biofertiliser. Annals of Applied Biology 168, 93-110. doi:10.1111/aab.12245

Antunes GR, Carvalho BR, Silva TR, Neiva JNM, Araújo GGL, FernandesJúnior PI (2017) Quantification and characterization of putative diazotrophic bacteria from forage palm under saline water irrigation. Geama 3, 261-268.

Baldani JI, Reis VM, Videira SS, Boddey LH, Baldani VLD (2014) The art of isolating nitrogen-fixing bacteria from non-leguminous plants using $\mathrm{N}$-free semi-solid media: a practical guide for microbiologists. Plant and Soil 384, 413-431. doi:10.1007/s11104-014-2186-6

Barazani O, Friedman J (1999) Is IAA the major root growth factor secreted from plant-growth-mediating bacteria? Journal of Chemical Ecology 25, 2397-2406. doi:10.1023/A:1020890311499

Berraquero FR, Baya B, Cormenzana AR (1976) Establecimiento de índices para el estudio de la solubilización de fosfatos por bacterias del suelo. Ars Pharmaceutica 17, 399-406.

Bertrand H, Nalin R, Bally R, Cleyet-Marel J-C (2001) Isolation and identification of the most efficient plant growth-promoting bacteria associated with canola (Brassica napus). Biology and Fertility of Soils 33, 152-156. doi:10.1007/s003740000305

Boddey RM, De Moraes Sá JC, Alves BJR, Urquiaga S (1997) The contribution of biological nitrogen fixation for sustainable agricultural systems in the tropics. Soil Biology \& Biochemistry 29, 787-799. doi:10.1016/S0038-0717(96)00221-0

Brasil M da S, Baldani JI, Baldani VLD (2005) Ocorrência e diversidade de bactérias diazotróficas associadas a gramíneas forrageiras do Pantanal Sul Matogrossense. Revista Brasileira de Ciência do Solo 29, 179-190. doi: 10.1590/S0100-06832005000200003

Brígido C, Oliveira S (2013) Most acid-tolerant chickpea mesorhizobia show induction of major chaperone genes upon acid shock. Microbial Ecology doi:10.1007/s00248-012-0098-7

da Silva JF, da Silva TR, Escobar IEC, Fraiz ACR, dos Santos JWM, do Nascimento TR, dos Santos JMR, Peters SJW, de Melo RF, Signor D, Fernandes-Júnior PI (2018) Screening of plant growth promotion ability among bacteria isolated from field-grown sorghum under different managements in Brazilian drylands. World Journal of Microbiology \& Biotechnology 34, 186. doi:10.1007/s11274-018-2568-7

de Oliveira DM, de Lima ALA, Diniz NB, Santos CERS, da Silva SLF, Simões AN (2018) Inoculation of plant-growth-promoting rhizobacteria in Myracrodruon urundeuva Allemão supports in tolerance to drought stress. Journal of Plant Interactions 13, 91-99. doi:10.1080/ 17429145.2018.1432770

de Souza R, Ambrosini A, Passaglia LMP (2015) Plant growth-promoting bacteria as inoculants in agricultural soils. Genetics and Molecular Biology 38, 401-419. doi:10.1590/S1415-475738420150053

dos Santos MCM, dos Santos DR, Bakke A, Bakke IA (2013) Ocorrência e atividade de bactérias diazotróficas em forrageiras cultivadas na rregião semiárida do Brasil. Caatinga 26, 27-34.

dos Santos CLR, Alves GC, de Matos Macedo AV, Giori FG, Pereira W, Urquiaga S, Reis VM (2017) Contribution of a mixed inoculant containing strains of Burkholderia spp. and Herbaspirillum ssp. to the growth of three sorghum genotypes under increased nitrogen fertilization 
levels. Applied Soil Ecology 113, 96-106. doi:10.1016/j.apsoil. 2017.02.008

Duca D, Lorv J, Patten CL, Rose D, Glick BR (2014) Indole-3-acetic acid in plant-microbe interactions. Antonie van Leeuwenhoek 106, 85-125. doi:10.1007/s10482-013-0095-y

Egamberdieva D (2008) Plant growth promoting properties of rhizobacteria isolated from wheat and pea grown in loamy sand soil. Turkish Journal of Biology 32, 9-15.

Egamberdiyeva D, Höflich G (2002) Root colonization and growth promotion of winter wheat and pea by Cellulomonas spp. at different temperatures. Plant Growth Regulation 38, 219-224. doi:10.1023/ A: 1021538226573

Estrada-de Los Santos P, Bustillos-Cristales R, Caballero-Mellado J (2001) Burkholderia, a genus rich in plant-associated nitrogen fixers with wide environmental and geographic distribution. Applied and Environmental Microbiology 67, 2790-2798. doi:10.1128/AEM.67.6.2790-2798. 2001

Fernandes Júnior PI, Pereira GMD, Perin L, da Silva LM, Baraúna AC, Alvess FM, Passos SR, Zilli JE (2013) Diazotrophic bacteria isolated from wild rice Oryza glumaepatula (Poaceae) in the Brazilian Amazon. Revista de Biología Tropical 61, 991-999. doi:10.15517/rbt.v61i2. 11238

Fernandes-Júnior PI, Aidar S de T, Morgante CV, Gava CAT, Zilli JÉ, de Souza LSB, Marinho R de CN, Nóbrega RSA, Brasil M da S, Seido SL, Martins LMV (2015) The resurrection plant Tripogon spicatus (Poaceae) harbors a diversity of plant growth promoting bacteria in northeastern Brazilian Caatinga. Revista Brasileira de Ciência do Solo 39, 993-1002. doi:10.1590/01000683rbcs20140646

Ferreira DF (2011) Sisvar: a computer statistical analysis system. Ciência e Agrotecnologia 35, 1039-1042. doi:10.1590/S1413-70542011000600 001

Glick BR (2005) Modulation of plant ethylene levels by the bacterial enzyme ACC deaminase. FEMS Microbiology Letters 251, 1-7. doi:10.1016/ j.femsle.2005.07.030

Gontijo JB, Andrade GVS, Baldotto MA, Baldotto LEB (2018) Bioprospecting and selection of growth-promoting bacteria for Cymbidium sp. orchids. Scientia Agrícola 75, 368-374. doi:10.1590/ 1678-992x-2017-0117

Haiyambo DH, Chimwamurombe PM, Reinhold-Hurek B (2015a) Isolation and screening of rhizosphere bacteria from grasses in East Kavango region of Namibia for plant growth promoting characteristics. Current Microbiology 71, 566-571. doi:10.1007/s00284-015-0886-7

Haiyambo DH, Reinhold-Hurek B, Chimwamurombe PM (2015b) Effects of plant growth promoting bacterial isolates from Kavango on the vegetative growth of Sorghum bicolor. African Journal of Microbiological Research 9, 725-729. doi:10.5897/AJMR2014.7205

Hungria M, Campo RJ, Souza EM, Pedrosa FO (2010) Inoculation with selected strains of Azospirillum brasilense and A. lipoferum improves yields of maize and wheat in Brazil. Plant and Soil 331, 413-425. doi:10.1007/s11104-009-0262-0

Hungria M, Nogueira MA, Araujo RS (2016) Inoculation of Brachiaria spp. with the plant growth-promoting bacterium Azospirillum brasilense: an environment-friendly component in the reclamation of degraded pastures in the tropics. Agriculture, Ecosystems \& Environment 221, 125-131. doi:10.1016/j.agee.2016.01.024

IBGE (2017) Censo Agropecuário 2017. IBGE, Rio de Janeiro, Brazil. Available at: https://censoagro2017.ibge.gov.br/templates/censo_agro/ resultadosagro/index.html

Kavamura VN, Santos SN, da Silva JL, Parma MM, Ávila LA, Visconti A, Zucchi TD, Taketani RG, Andreote FD, de Melo IS (2013) Screening of Brazilian cacti rhizobacteria for plant growth promotion under drought. Microbiological Research 168, 183-191. doi:10.1016/j.micres.2012. 12.002

Kuss AV, Kuss VV, Lovato T, Flôres L (2007) Fixação de nitrogênio e produção de ácido indolacético in vitro por bactérias diazotróficas endofíticas. Pesquisa Agropecuária Brasileira 42, 1459-1465. doi:10.1590/S0100-204X2007001000013

Leite R da C, Santos JGD dos, Silva EL, Alves CRCR, Hungria M, Leite R da C, Santos AC dos (2019a) Productivity increase, reduction of nitrogen fertiliser use and drought-stress mitigation by inoculation of Marandu grass (Urochloa brizantha) with Azospirillum brasilense. Crop \& Pasture Science 70, 61-67. doi:10.1071/CP18105

Leite R da C, Santos AC dos, Santos JGD dos, Leite R da C, Oliveira LBT de, Hungria M (2019b) Mitigation of Mombasa grass (Megathyrsus maximus) dependence on nitrogen fertilization as a function of inoculation with Azospirillum brasilense. Revista Brasileira de Ciência do Solo 43, 1-14. doi:10.1590/18069657rbcs20180234

Liao CFH (1981) Devarda's alloy method for total nitrogen determination. Soil Science Society of America Journal 45, 852-855. doi:10.2136/ sssaj1981.03615995004500050005x

Lima JVL, Weber OB, Correia D, Soares MA, Senabio JA (2015) Endophytic bacteria in cacti native to a Brazilian semi-arid region. Plant and Soil 389, 25-33. doi:10.1007/s11104-014-2344-x

Mazzetto AM, Barneze AS (2016) Nitrogen fertilizer effects on nitrous oxide emission from southwest Brazilian Amazon pastures. Journal of Fertilizers \& Pesticides 07, 1-5. doi:10.4172/2471-2728.1000167

Moreira JN, Guimarães Filho C (2011) Sistemas tradicionais para produção de caprinos e ovinos. 'Produção caprinos e ovinos no Semiárido'. (Ed. TV Voltolini) pp. 49-67. (Embrapa Semiárido: Petrolina, Brazil)

Moreira JN, Lira M de A, dos Santos MVF, Ferreira M de A, de Araújo GGL, Ferreira RLC, da Silva GC (2006) Caracterização da vegetação de Caatinga e da dieta de novilhos no Sertão de Pernambuco. Pesquisa Agropecuária Brasileira 41, 1643-1651. doi:10.1590/S0100-204X200 6001100011

Moreira FTA, Santos DR, Silva GH, Alencar LS (2013) Ocorrência de bactérias do gênero Azospirillum spp. associadas a gramíneas forrageiras no semiárido nordestino. Holos 3, 205-212. doi:10.15628/holos. 2013.1043

Poly F, Monrozier LJ, Bally R (2001) Improvement in the RFLP procedure for studying the diversity of nifH genes in communities of nitrogen fixers in soil. Research in Microbiology 152, 95-103. doi:10.1016/S0923-2508 (00)01172-4

Reis Junior, FB, Silva MF, Teixeira KRS, Urquiaga S, Reis VM (2004) Identificação de isolados de Azospirillum amazonense associados a Brachiaria spp., em diferentes épocas e condições de cultivo e produção de fitormônio pela bactéria. Revista Brasileira de Ciência do Solo 28, 103-113. doi:10.1590/S0100-06832004000100011

Ribeiro CM, Cardoso EJBN (2012) Isolation, selection and characterization of root-associated growth promoting bacteria in Brazil pine (Araucaria angustifolia). Microbiological Research 167, 69-78. doi:10.1016/ j.micres.2011.03.003

Rodrigues Neto J, Malavolta Jr VA, Victor O (1986) Meio simples para o isolamento e cultivo de Xanthomonas campestris pv. citri tipo B. Summa Phytopathologica 12, 32.

Sarwar M, Kremer RJ (1995) Determination of bacterially derived auxins using a microplate method. Letters in Applied Microbiology 20, 282-285. doi:10.1111/j.1472-765X.1995.tb00446.x

Schwyn B, Neilands JB (1987) Universal chemical assay for the detection and determination of siderophores. Analytical Biochemistry 160, 47-56. doi:10.1016/0003-2697(87)90612-9

Signor D, Cerri CEP (2013) Nitrous oxide emissions in agricultural soils: a review. Pesquisa Agropecuária Tropical 43, 322-338. doi:10.1590/ S1983-40632013000300014

Silva MCP, Figueiredo AF, Andreote FD, Cardoso EJBN (2013) Plant growth promoting bacteria in Brachiaria brizantha. World Journal of Microbiology \& Biotechnology 29, 163-171. doi:10.1007/s11274012-1169-0

Singh RP, Jha PN (2017) The PGPR Stenotrophomonas maltophilia SBP-9 augments resistance against biotic and abiotic stress in wheat plants. Frontiers in Microbiology 8, doi:10.3389/fmicb.2017.01945 
Soares RA, Roesch LFW, Zanatta G, de Oliveira Camargo FA, Passaglia LMP (2006) Occurrence and distribution of nitrogen fixing bacterial community associated with oat (Avena sativa) assessed by molecular and microbiological techniques. Applied Soil Ecology 33, 221-234. doi:10.1016/j.apsoil.2006.01.001

Souza MST, Baura VA, Santos SA, Fernandes-Júnior PI, Reis Junior, FB, Marques RM, Paggi GM, Brasil MS (2017) Azospirillum spp. from native forage grasses in Brazilian Pantanal floodplain: biodiversity and plant growth promotion potential. World Journal of Microbiology \& Biotechnology 33, 81. doi:10.1007/s11274-017-2251-4

Sylvester-Bradley R, Asakawa N, La Torraca S, Magalhães FM, Oliveira LA, Pereira RM (1982) Levantamento quantitativo de microrganismos solubilizadores de fosfatos na rizosfera de gramíneas e leguminosas forrageiras na Amazônia. Acta Amazonica 12, 15-22. doi:10.1590/ 1809-43921982121015

Vendan RT, Yu YJ, Lee SH, Rhee YH (2010) Diversity of endophytic bacteria in ginseng and their potential for plant growth promotion. Journal of Microbiology 48, 559-565. doi:10.1007/s12275-010-0082-1
Voltolini TV (Ed.) (2011) 'Produção de caprinos e ovinos no Semiárido.' (Embrapa Semiárido: Petrolina, Brazil)

Wang H, Qi M, Cutler AJ (1993) A simple method of preparing plant samples for PCR. Nucleic Acids Research 21, 4153-4154. doi:10.1093/nar/ 21.17.4153

Weisburg WG, Barns SM, Pelletier DA, Lane DJ (1991) 16S ribosomal DNA amplification for phylogenetic study. Journal of Bacteriology 173, 697-703. doi:10.1128/jb.173.2.697-703.1991

Yoon S-H, Ha S-M, Kwon S, Lim J, Kim Y, Seo H, Chun J (2017) Introducing EzBioCloud: a taxonomically united database of $16 \mathrm{~S}$ rRNA and whole genome assemblies. International Journal of Systematic and Evolutionary Microbiology 67, 1613-1617. doi:10.1099/ijsem.0. 001755

Zinniel DK, Lambrecht P, Harris NB, Feng Z, Kuczmarski D, Higley P, Ishimaru CA, Arunakumari A, Barletta RG, Vidaver AK (2002) Isolation and characterization of endophytic colonizing bacteria from agronomic crops and prairie plants. Applied and Environmental Microbiology 68 , 2198-2208. doi:10.1128/AEM.68.5.2198-2208.2002 